\title{
Effect Addition method of Organic Fertilizer( Humic Acid) on Growth ,Yield and Active Ingredients of Allium sativum $L$.
}

\author{
Dr.Ayyub J.Abdl-Rahmaan Abayaty
}

Department of Biology,College of Women Education,Tikrit University

\begin{abstract}
A field experiment was conducted in College ducation for Women / Tikrit University during 2017 - 2018 season to study the effect of two addition method sprying the plant and sprying the soil of organic fertilizer humic acid with four concentration $(1 \mathrm{ml} / 1,2 \mathrm{ml} / 1,3 \mathrm{ml} / 1,4 \mathrm{ml} / 1$ in addition of control(without treartment) on the growth , yield and active ingredients of Allium sativum, The experiment was factorial according to split plot design, addition method take the main plots while the concentration take the secondary plots with three replication, results showed sprying the soil with humic acid led to significant increase on vegetative growth and yield characteristics and high value gained by spring the soil with concentration $4 \mathrm{ml} / 1$ on compar with plant spray treatment.Analy sis by using HPLC teqnique appeared existence many active ingredients on the leaves and cloves of plant as: S-allyl cysteine, Y-glutomyl cysteine, Allicin, Vinyl-\{4H\}1.2dithlin (agoene), di-allyldisulfide and Diallyltrisulfide and higher percentage from allicin compound were at soil spray method with $3 \mathrm{ml} / 1$ humic acid reacched $54.59 \%$.
\end{abstract}

\section{Introduction}

In the last years focus was on adoption on agricultural practices in particular fertilization with modern techniques and correct environmentally thus ensuring high productivity and quality products and reduce negative impact on environment [1],chemical fertilizer has great harm both on human health throw big increase on elements concentration and some compounds in the plant which adversely affects on human health,also throw increasing chemical fertilizer had advers effect on soil useful organism and degradation of soil properties and resulting economic losses,all this causes urge specialists in agriculture to rely on organic fertilizers [2],the modern studies proved particulary the resulting danger of the remaining trace of nitrate which is considered from more dangerous compounds on human health [3],the chemical fertilizer dangerous comes from it doesn't metabolis $m$ on the body and its fixation on alkloidal soil and the higher its price [4] therfor g lobal attention focus on organic fertilizers for many crops and vegetables [5],and organic agriculture concedred from the most important environmental regulations which restore for the environment its balance and provides health production wanted for human nutrition [6],verily using humid ifiers and its acids as humic acid concider one of organic nutrition kind [7].Hu mic acid fertilizer is one of the decomposing materrials produced from organic materials [8],assist to improve absorption of nutrients, create a good soil environ ment,improve plant ability on water retention and stimulate gro wth and activity soil microorganism particularly the responsible of ferment organic matter [9].

The chemical nature of humates is complex and depend to the source which consists of [10], and it origion from physical and biochemical transformation of living molecules and it has many types of salts as calisiu m hu mates, sodium humates, amonium humates and potassium humates [11] it improve soil quality and productivity on addition improving soil physical properties, And retention of soiland increasing interchangeable capacity which is important for soil fertility [12].

Allium sativum consider second important vegetative crops of Alliaceae family after onion crop [13] , and its important winter vegetative crops on Iraq and the world for its high nutrition value, the frequent uses and its many benefits [14].the lobes contain 31\% carbohydrates, $6.29 \%$ proteins and its rich with elements as phosphorus, iron,potassium, magnesium,vitamins as riboflavin,niasin and ascorbic acid and it contain the most important compound Allic in which inhibitor growth of many nambers of bacteria,fungi 
and viruses[Ankar and mirelman[15],[ 16] studies refer to superior organic fertilizer on growth properties of Califlower[17] and treatment with humic acid gave high yield from Allium sativum reached $3.38 \mathrm{t} / \mathrm{do}$. And increasing its content from fatty acids [18].

\section{2-Materials and methods:}

Afield experimen conducted using plastic pots $30 \mathrm{~cm}$ diameter and 30c $\mathrm{mh}$ igh during the seas on 2017-2018 using sandy sailty soil treated with compound fertilizer $\mathrm{N}, \mathrm{P}, \mathrm{K}(20,20,20)$ the planting date were $15 / 10 / 2017$ each treatment contain 5 plant to study effect of two method addition sprying plant and spryng soil with organic fertilizer (hu mic acid) in growth ,yield components and the contents of active constituents of garlic plant,using factorial experiment in CRD design.the first factor were sprayin the plant with by concentration $(1 \mathrm{~m} / \mathrm{L}, 2 \mathrm{~m} / \mathrm{L} .3 \mathrm{~m} / \mathrm{L}, 4 \mathrm{~m} / \mathrm{L})$ in addition to control treatment, the second factor were spraying the soil with same concentration, the number of treatment were 10 with three replication.Harvesting of crop were 10/5/2018 and the data taken on the harvest date as range three plants,to study growth properties:plant high $(\mathrm{cm})$, leaves number.plant-1,stem diameter $(\mathrm{cm})$,Total clorophyll and yield properties:Head diameter(cm),lobs numer.head-1,lob weight(gm),head weight(gm) and active constituent of the plant.

2.1. Chlorophyll determin:wet weight $(0.5) \mathrm{g} \mathrm{m}$ from leaves put on dark glass butlle then $(20) \mathrm{ml}$ aceton by $80 \%$ concentration added.and leaft for 24 hours the process replicate more than once to extract ch lorophyll completely,the size of extract reach(50)ml and chlorophyll estimated according [19]through reading the extract absorption on the wave length $(645-663) \mathrm{nm}$ by spectrophotometerapparatus.

2.2.Determin Activ ingredients of plant:Active ingredients on lobs of plant determined by using High Performance Liquid Chromotography ( HPLC) teqnique. The plant dried at the shade and milled then 10 gm from the sample put in $50 \mathrm{ml}$ boiled water (90-100C0) for 3 hours then extracted whattman papers no. 1 the extraction collected and put in closed glass tube[ weeraching\&Dung 1998]20] in order measuring the concentration of active ingredients by (HPLC) apparatus at condition show in (table 1)and the data recorded by calculator which drawed the peak area and retention time.Astandard solution of Allium sativ $\mathrm{m}$ plant used and sperated by HPLC apparatus and identification the pick area and retention time of standard solution and comparing it with the pick area and retention time of studed plant sample at the same condition[21].

Concentration of compounds in the sample calculated by the aquation : peak area of compound

Conc. Compound in the plant $=$ $\times$ standard pattern conc.xdelution factor peak area of standard pattern

Table 1. Chromatographics separate condition.

\begin{tabular}{|c|c|c|c|c|c|c|}
\hline Colum & $\begin{array}{l}\text { Mobile } \\
\text { phase }\end{array}$ & $\begin{array}{l}\text { Following } \\
\text { rate }\end{array}$ & $\begin{array}{l}\text { Type of } \\
\text { detector }\end{array}$ & Temperature & $\begin{array}{l}\text { Fast of } \\
\text { recorder paper }\end{array}$ & $\begin{array}{l}\text { Size of } \\
\text { injected sample }\end{array}$ \\
\hline Reverse & Dis till & $10 \mathrm{ml} / \mathrm{min}$ & Ultra & $25 C^{0}$ & $10 \mathrm{mml} / \mathrm{min}$ & $20 \mu l$ \\
\hline phase & water & & violate ray & & & \\
\hline column & Ethanol 70\% & & $250 \mathrm{~nm}$ & & & \\
\hline$(50 \times 4.6$ & $2: 80 \mathrm{v} / \mathrm{v}$ & & & & & \\
\hline mm I.D) & & & & & & \\
\hline
\end{tabular}

The means compared according Duncan test at significan level 5\% using program[22.

3.Results and discussion: 
The results of table (2)significant effect of treatment with humic acid on the growth properties in compar with control treatment also their were difference between method of uses and the used concentration,all the vegetative parameters increased with increasing humic acid concentration when spryed the plant and sprying the soil,the highest values when sprayed the soil with $4 \mathrm{~m} / 1$ concentration reached $77.26,14.58,1.70$ and 24.10 for parametrs plant high $(\mathrm{cm})$,nu mber of leaves.plant-1,stem diameter $(\mathrm{cm})$ and total chlorophyll $(\mathrm{mg} / \mathrm{g})$ respectively,while the least values were on control treatment when plant spry method reached $30.42,6.0,0.80$ and 20.11 for plant high $(\mathrm{cm})$,number of leaves.plant-1,stem diameter $(\mathrm{cm})$ and total chlorophyll(mg/g) respectively.

table (3) appear the significant effect of method of treatment and the effect of the difference between the concentration on the yield parameters. The highest values were in the sprying soil method by $4 \mathrm{~m} / 1$ concentration reached 3.81,12.0,5.30 and 55.70 for the parameters head diameter $(\mathrm{cm})$,number of lobs.plant-1,lob weight $(\mathrm{gm})$ and head weight $(\mathrm{gm})$ respectively.,while the least values on the same method were on control treatment reached 2.80,7.10,1.88 and 18.0 for the parameters head diameter (cm),number of lobs.plant-1,lob weight $(\mathrm{gm})$ and head weight $(\mathrm{gm})$ respectively. The reas on of the increasing on vegetative and yield parameters may due to to the role of organic fertilization(humic acid) on imoroving soil bio ,chemical and physical properties and increasing its ability to absorption water and increasing its content from minor nutrient elements specialy nitrogen,phosphorus and potassium[23], and the increasing on nitrogen concentration led increase on formation chlorophyll pigments and this increase photosynthesis process[24],also humic acid affect on exchange capacity which led to increase the nutrient element and improve soil texture and this easing root growth inside the soil which led to absorption more of water and elements and this affect on vegetative group as plant hight and other vegetative and yield paramete[25] [26].the analysis of humic acid gave carbonic acid which is weak acid analysis to ion(H+) and (HCO3-) and this contribute on change soil $(\mathrm{pH})$ assisting on desolving some macronutrients mineral elements as $\mathrm{P}, \mathrm{K}, \mathrm{Mg}, \mathrm{Ca}$ and available some micronutrients and this absorbed by the plant and increasing plant physiology action which reflect possitvly on both growth and yield parameters.[27]

The analysis of standar patterns of the Allium sativum plant by HPLC apparatus appeared verily the plant contain several compounds: S-allyl cysteine, Y-glutomyl cysteine, Allicin, Viny $1-\{4 \mathrm{H}\} 1.2$ dithlin (agoene), di-allyldisulfide and Diallyltrisulfide (Figure 1 and table 5), while analysis studied plant

by HPLC teqnique showe higher contain the plant from allicin compound reached $54.59 \%$ when soil spraying method with concentration $3 \mathrm{ml} / 1$ from humic while.

Table 2.Effect of treatment method with humic acid on vegetative properties of Allium sativum $L$. Properties

\begin{tabular}{|c|c|c|c|c|c|}
\hline properties & & plant high $(\mathrm{cm})$ & $\begin{array}{c}\text { Number } \\
\text { leaves.plant-1 }\end{array}$ & $\begin{array}{l}\text { Stem diameter } \\
(\mathrm{cm})\end{array}$ & $\begin{array}{c}\text { Total } \\
\text { Chlorophyll }\end{array}$ \\
\hline \multirow{5}{*}{ soil spry } & 0 & $42.41 \mathrm{e}$ & $5.26 \mathrm{~d}$ & $0.80 \mathrm{c}$ & $20.0 \mathrm{c}$ \\
\hline & $1 \mathrm{ml} / 1$ & $53.85 d$ & $7.24 \mathrm{c}$ & $1.13 b$ & $21.39 b c$ \\
\hline & $2 \mathrm{ml} / 1$ & $67.58 \mathrm{c}$ & $12.04 \mathrm{~b}$ & $1.90 \mathrm{a}$ & $22.60 \mathrm{~b}$ \\
\hline & $3 \mathrm{ml} / 1$ & $72.30 \mathrm{~b}$ & $12.90 \mathrm{~b}$ & $1.90 \mathrm{a}$ & $22.60 \mathrm{~b}$ \\
\hline & $4 \mathrm{~m} / 1$ & $77.26 a$ & $14.58 \mathrm{a}$ & $1.70 \mathrm{a}$ & $24.10 \mathrm{a}$ \\
\hline plan spry & 0 & $30.42 d$ & $6.0 \mathrm{~cd}$ & $0.70 \mathrm{~cd}$ & $20.11 b$ \\
\hline
\end{tabular}




\begin{tabular}{|c|c|c|c|c|c|}
\hline & $1 \mathrm{ml} / \mathrm{l}$ & $50.48 \mathrm{~d}$ & $7.01 \mathrm{c}$ & $0.80 \mathrm{c}$ & $21.12 \mathrm{~b}$ \\
\cline { 2 - 6 } & $2 \mathrm{ml} / \mathrm{l}$ & $65.49 \mathrm{c}$ & $11.01 \mathrm{~b}$ & $1.00 \mathrm{~b}$ & $21.40 \mathrm{~b}$ \\
& & & & & $23.0 \mathrm{a}$ \\
\cline { 2 - 6 } & $3 \mathrm{ml} / 1$ & $70.11 \mathrm{ab}$ & $11.10 \mathrm{~b}$ & $1.08 \mathrm{~b}$ & $23.90 \mathrm{a}$ \\
\cline { 2 - 6 } & $4 \mathrm{~m} / 1$ & $73.13 \mathrm{a}$ & $13.0 \mathrm{a}$ & $1.20 \mathrm{a}$ & \\
\hline
\end{tabular}

* Same laters on one column mean no significantly difference at the level $5 \%$.

Table 3.Effect of treatment method with humic acid on growth components of Allium sativum $L$.

\begin{tabular}{|c|c|c|c|c|c|}
\hline properties & & $\begin{array}{c}\text { Head } \\
\text { diameter }(\mathrm{cm})\end{array}$ & $\begin{array}{c}\text { Number lobs.head- } \\
1\end{array}$ & $\begin{array}{c}\text { Lob } \\
\text { weight }(\mathrm{gm})\end{array}$ & $\begin{array}{c}\text { Head } \\
\text { weight }(\mathrm{gm})\end{array}$ \\
\hline treatment & & & & & \\
\hline & 0 & $2.81 \mathrm{bcd}$ & $7.01 \mathrm{~cd}$ & $1.91 \mathrm{dc}$ & 17.17de \\
\hline soil spry & $1 \mathrm{ml} / 1$ & $3.01 \mathrm{~cd}$ & $8.15 b c$ & $2.00 \mathrm{bc}$ & $19.45 \mathrm{~d}$ \\
\hline & $2 \mathrm{ml} / 1$ & $3.11 \mathrm{abc}$ & $8.21 b c$ & $3.13 b$ & $32.30 \mathrm{c}$ \\
\hline & $3 \mathrm{ml} / 1$ & $3.32 \mathrm{ab}$ & $9.0 \mathrm{~b}$ & $3.60 \mathrm{~b}$ & $40.04 b$ \\
\hline & $4 \mathrm{~m} / 1$ & $3.81 \mathrm{a}$ & $12.0 \mathrm{a}$ & $5.30 \mathrm{a}$ & $55.70 \mathrm{a}$ \\
\hline & 0 & $2.80 \mathrm{bcd}$ & $7.10 \mathrm{bcd}$ & $1.88 \mathrm{de}$ & $18.0 \mathrm{e}$ \\
\hline & $1 \mathrm{ml} / 1$ & $3.10 \mathrm{~cd}$ & $8.25 b c$ & $2.02 \mathrm{~cd}$ & $20.45 \mathrm{de}$ \\
\hline & $2 \mathrm{ml} / 1$ & $3.21 \mathrm{abc}$ & $8.61 b c$ & $3.33 b c$ & $35.31 \mathrm{c}$ \\
\hline & $3 \mathrm{ml} / 1$ & $3.44 a b$ & $10.30 \mathrm{abc}$ & $4.12 \mathrm{ab}$ & $45.60 \mathrm{~b}$ \\
\hline & $4 \mathrm{~m} / 1$ & 3.55 & 11.51 & 4.83 & 50.12 \\
\hline
\end{tabular}

* Same laters on one column mean no significantly difference at the level $5 \%$.

analaysis by HPLC apparatus proved its activity in fast on diagnosis this compounds through its ability on calculating the curve with its hight and determine active ingredients in one ope ration [35] It is also has the advantage in compare with other methods such as GC by ability on the dealing with non volatail materials including inorganic ions and thermally stable materials [36], results of study agree with [24][37] whom refers To contain A. sativum to Allicin compound and agree with[38] whom confirmed contain this plant to sulfide compounds. 


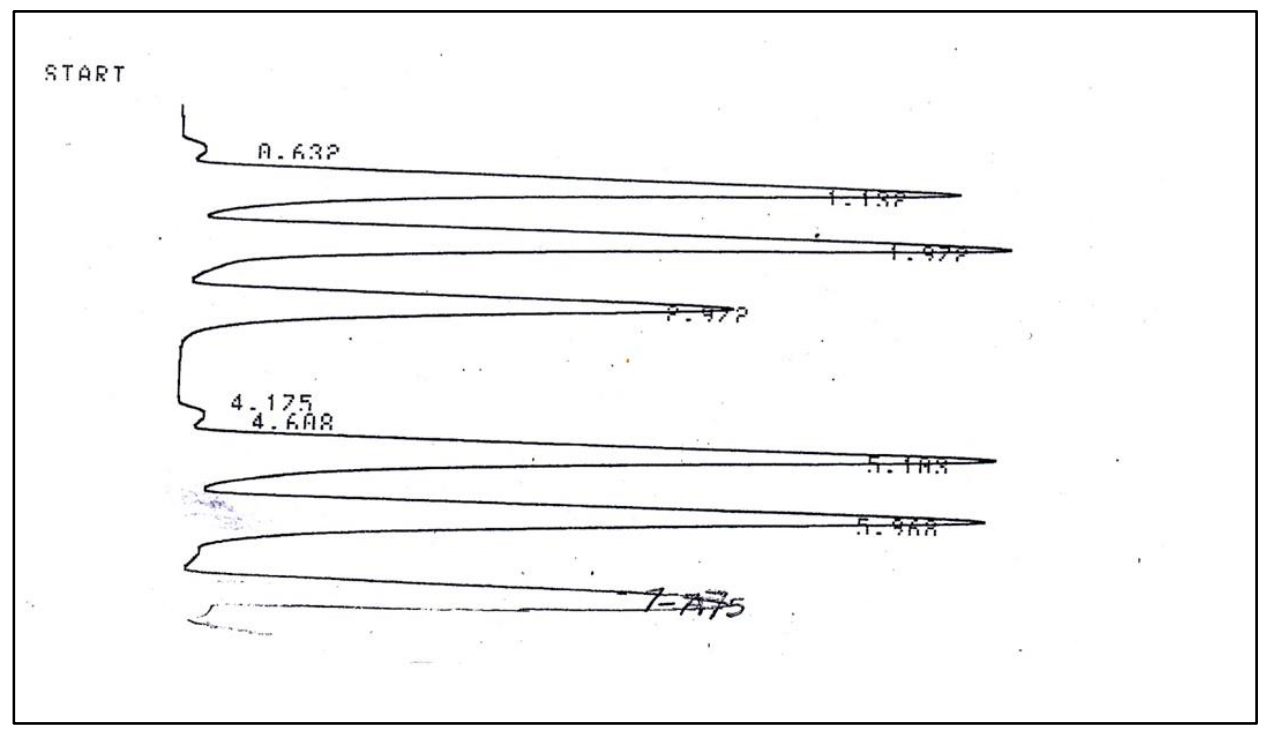

Figure 1.Retention time and Peak area of Allium sativum plant standard pattern.

Table 4.Compounds ,Pick area and the concentration of Allium sativum plant standard solution

\begin{tabular}{lccc}
\hline Compounds & Retention time & Peak Area & Concentration(mg/ml) \\
S-Allyl cystine & 1.22 & 30583 & 25 \\
Y-Glutomyl cysteine & 1.95 & 32646 & 25 \\
Allicin & 2.99 & 24533 & 25 \\
Vinyl-4H-1,2 dithilin(Agoene & 5.20 & 35445 & 25 \\
Diallyl disulfide & 5.88 & 34993 & 25 \\
Diallyl trisulfide & 8.07 & 21989 & 25
\end{tabular}

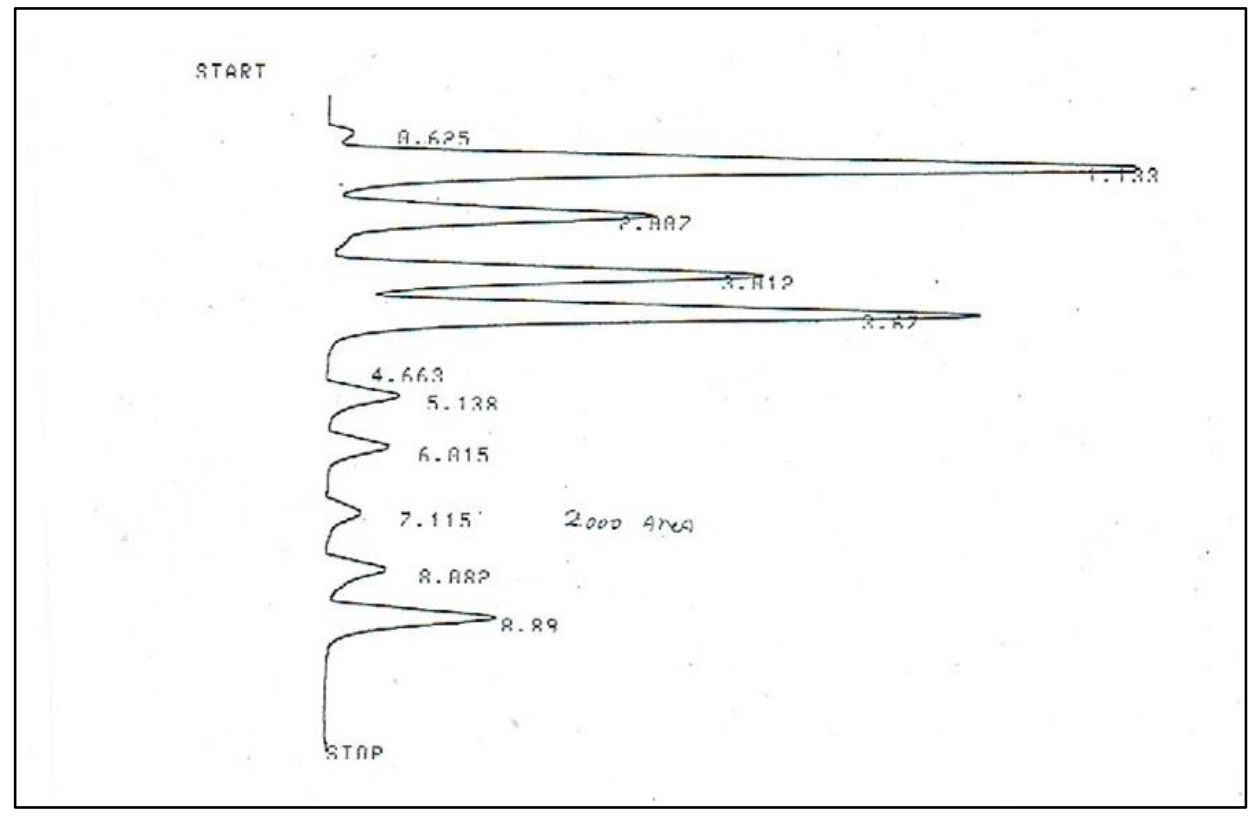

Figure 2.Retention time and Peak area of Allium sativum studied plant. 
Table 5.effect of treatment method with humic acid on active ingredients concentration (\%) of studied Allium sativum L.plant. Compounds

\begin{tabular}{|c|c|c|c|c|c|}
\hline properties & & Head diameter $(\mathrm{cm})$ & Number lobs.head-1 & $\begin{array}{c}\text { Lob } \\
\text { weight }(\mathrm{gm})\end{array}$ & $\begin{array}{c}\text { Head } \\
\text { weight }(\mathrm{gm})\end{array}$ \\
\hline \multirow{5}{*}{ soil spry } & 0 & $2.81 \mathrm{bcd}$ & $7.01 \mathrm{~cd}$ & $1.91 \mathrm{dc}$ & $17.17 \mathrm{de}$ \\
\hline & $1 \mathrm{ml} / 1$ & $3.01 \mathrm{~cd}$ & $8.15 b c$ & $2.00 \mathrm{bc}$ & $19.45 d$ \\
\hline & $2 \mathrm{ml} / 1$ & $3.11 \mathrm{abc}$ & $8.21 b c$ & $3.13 b$ & $32.30 \mathrm{c}$ \\
\hline & $3 \mathrm{ml} / 1$ & $3.32 \mathrm{ab}$ & $9.0 \mathrm{~b}$ & $3.60 \mathrm{~b}$ & $40.04 b$ \\
\hline & $4 \mathrm{~m} / 1$ & $3.81 \mathrm{a}$ & $12.0 \mathrm{a}$ & $5.30 \mathrm{a}$ & $55.70 \mathrm{a}$ \\
\hline \multirow{5}{*}{ Soil spry } & 0 & $2.80 \mathrm{bcd}$ & $7.10 \mathrm{bcd}$ & $1.88 \mathrm{de}$ & $18.0 \mathrm{e}$ \\
\hline & $1 \mathrm{ml} / 1$ & $3.10 \mathrm{~cd}$ & $8.25 b c$ & $2.02 \mathrm{~cd}$ & $20.45 \mathrm{de}$ \\
\hline & $2 \mathrm{ml} / 1$ & $3.21 \mathrm{abc}$ & $8.61 b c$ & $3.33 b c$ & $35.31 \mathrm{c}$ \\
\hline & $3 \mathrm{ml} / 1$ & $3.44 a b$ & $10.30 \mathrm{abc}$ & $4.12 \mathrm{ab}$ & $45.60 \mathrm{~b}$ \\
\hline & $4 \mathrm{~m} / 1$ & 3.55 & 11.51 & 4.83 & 50.12 \\
\hline
\end{tabular}

* Same laters on one column mean no significantly difference at the level $5 \%$.

\section{Refrences:}

[1] Chen, Y. and Avaid, T. (1990). Effect of humic substances on Plant growth. Pp.161-186. In: American Society of Agronomy and Soil Science Society of America (eds.), Humic substances in soil and crop science; selected Readings. American Society of Agronomy, Madison, WI.

[2] Al-Zahawi,S.M.A.(2007).Effect of different organic fertilizer and mulching on growth ,production and quality of Solanum tuberosum L. Ms.theses,college of Agriculture,Baghdad University.Iraq .

[3] Othman,J.Y.(2007).Study effect using organic fertilizer on culturing and production of Solanum tuberosum L. as intput on clean organic production. Ms.theses,college of Agriculture,Narain University,Syria.

[4] Al-Tememe,J.Y.(2009).Effect of humic acid and searbs extracts on growth and chmical properties of Rosemarinus officinalis L.sixth conference of biology dept.College of Education,Tikrit University,Iraq.:1 17.

[5] Willer,H.and Yusessefi,M.(2006).The word Of organic Agriculture Statistics and emerging trends 2006 InternationalEfedration of Organic Agriculture Movemen (IFOAM),Bohn, Germany. And Research Institute of Agriculture (FIBL),Frick,Switzerland. 
[6] Mohmmad,R.S.(2002).Comparision organic agriculture with classic agriculture on production Cucmis sativus L.and soil fertilization. Ms.theses,college of Agriculture,Baghdad University.Iraq .

[7] Al-Tememe,J.Y.and Bas ma,H.A.(2009).Effect of organic fertilizer and chelating iron on vegetative growth properties of Mentha piperita L.Tikritv J.Agric. Sci.2(14):181-187.

[8] Leonard, A. G. (2008). Humic Acid: 100\% Natural, Many Uses. Golden Harrest Organic., LLCTM.

[9] Al-Gartany,A.A.,\&Al-Saamray,A.A.(2008).Effect of biofertilizer with fungi Glomus mosseae and Trichoderma hazianum and organic fertilizer humic acid and their combination on balance N,P,K on Lycopersicon esculentum Mill. Tikritv J.Agric. Sci.2(8):256-280.

[10] Eladia,M.,Pena,M.,Josef,h.,and Jiri,P.(2005).Humic substances application in Agriculture,industry,environment, and biomedicine J.apple.BIOMED.3:13.

[11] Buckan, G. , Hooker, P. ,and Moulin , V. (2000). Versatile companents of plant soils and water In : Ghabbour E.A. and Davies G.(eds): Humic Substabces, RSC.Cambridge.

[12] Zhang,M.and He.Z.(2004).long-term Changes in organic carbon and

nutration of an Ultisol under rice cropping in southeast China

Geoderma, 118:167-179.

[13] Al-Shammary,A.M.\&Al-Mfargi,O.Kh.(2015).Effect of organic and chemical fertilization and their combination on growth and yield for two garlic cultivars of Allium sativum L.Diala J.Agric. sci.2(7).

[14] Hasan,A.A.(2007).Bioteqnology and plant breeding.Adar Alarabia for publication and distribution.Egypt.

[16] Al-Bayaty,A.J.;Abdulraheem.A.A\&Altef.R.H.(2018). Determain kind and concentration of Heliotropium suaveolens,Plantago major and Silybum marianum plants ingredients and its effect on some plant pathogenic fungi IOP Conf. Series: Journal of Physics: Conf. Series 1003 (2018) 012008

[17] Abbas,Kh,;Hadi,Y.;Hussen,J.\&Kahtan,A.J.(2013).Effect of sewage Sludge,Humic acid and mineral sepray of some traits of Califlower.Furat J.Agric Sci.5(4):316-323.

[18] Zahwan.T.A,;Nadhim,A.A.\&Ziyad,Kh.S.(2013).Effect of humic acid and nutrient solution prosol in growth ,yield garlic Allium sativum L.and content from fatty acid.Diala J.Agric. Sci.5(1):159-169.

[19] Bajracharya,D.(1999).Experiments in plant physiology.Narosa publishing Host.New Delhi.India.

[20] Weerachai,P.and Duang,B.(1998).simple isolation and purification of glycyrhizic acid. J.Sci.Fac.Cmu.25(2):87-91.

[21] Nishizawa,H.;Okimura,S.and Abe,Y.(1991).Application liquid particle purification of glycyrrhizin.Chemical pharm.Bull.39.969 - 971.

[22] SAS.(2001).Users Guide,Statistics(Version 6.121)SAS.Inst.Cary,N.C.USA.

[23] Al-Sahhaf,F.H.and Aaty,A.S.(2007).Effect of organic on growth and yield of tubes and its quality.Iraq,J.Agric sci48(4):65-82.

[24] Al-Sahhaf,F.H.(1989).Natural plant nutrition.Baghdad Unuversity.Ministry of Higher Education and Scientific Research.Iraq.

[25] Sarheed,M.M.(2012).Effect of addition organic fertilization to soil and spray with extract of sea herbbs Kelpak and Ultra kelpak 40 on growth and active ingredients of Apium graveolens L. Ms.theses,college of Agriculture,Tikrit University.Iraq .

[26] Omar,T.J.and Salih,Sh.M.(2018).The effect of humic acid and sea algae extracts on the growth ,for Lepidium sativum and aloe vera plants . Tikritv J.Agric. Sci.18(3):22-32.

[27] Al-Tememe ,J.Y.and Al-Dory,T.O.(2011).Effect spraying micronutrient on growth and chemical contents and active ingredients of Apium graveolens L. seventh conference,Bio.Dept. Colli.Education,Tkrit University.

[28] Al-Hedwony, A.K.H. 2004. Effect Fertilization and foliar application of some nutrient elements on quantitative and qualitative of some active compounds in seed two kind of (Trigon olla foenum) Ph.D Theses. Col. Agric. Univ. Baghdad, Iraq.

[29] Settle, F.A. 1997. Handbovk of instrumental techniques for analytic chemistry. N.J . Prentic Hall PTR:945

[30] Tsao, S.M.; Yin, M.C. 2001. Invitro antimicrobial activity of four diallyl sulphides occurring naturally in garlic and chinese leek oils. J. Med. Microbial, 50:646-649.

[31] Ankri, S. and Mirelman, D. 1999. Antimicrobial properties of allicin from garlic, Microbes and Infect, 2: 125-129.

[32] Lawson, L. D.; Wood, S.G. and Hughes, B.G. 1991. HPLC analysis of allic in and other thiosulfinates in garlic clove homogenates . Planta Med. 57(3): 263-70. 